\title{
JESSIE HARLAN LINCOLN IN IOWA
}

\author{
By Dr. Louis A. Haselmayer \\ lowa Wesleyan College, Mount Pleasant, lowa
}

Annals of Iowa, April 1957, published a brief item, “Jessie Lincoln Studied in Iowa," reprinted from the Illinois Journal of History. This included a newspaper clipping, undated and unidentified as to source:

Miss Jessie Harlan Lincoln, the daughter of Robert T. Lincoln, American minister to England, has entered the Iowa Wesleyan university in Mount Pleasant, Iowa, and will take the classical course.

Some general information was provided about the Robert Todd Lincoln family and the marriage of Jessie Lincoln to Warren Beckwith. No verification of this quotation has ever been provided and the article poses an unanswered question. The answer is available in the Archives of Iowa Wesleyan College, but it should be placed into the events of a long relationship of Mrs. Robert Todd Lincoln, mother of Jessie Harlan Lincoln, with Mount Pleasant, Iowa.

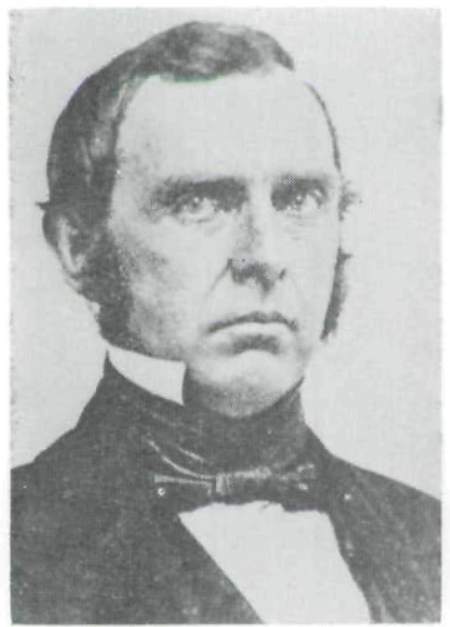

courtesy of Iowa Wesleyan College James Harlan

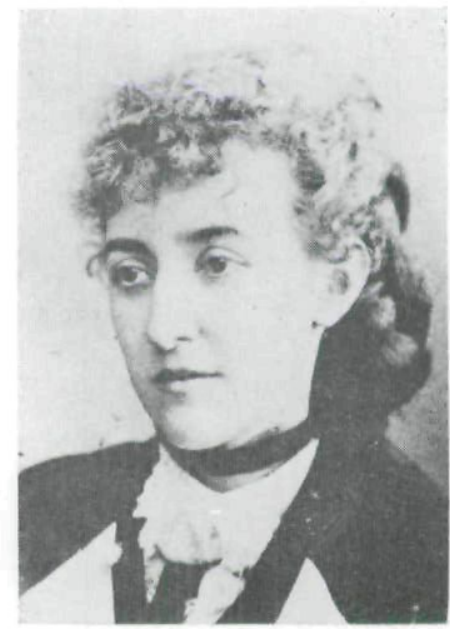

contesy of Iowa Wesleyan College Mary Harlan Lincoln 
Mrs. Robert Todd Lincoln (Mary Eunice Harlan) was the daughter of United States Senator James Harlan of Mount Pleasant. He had been president of the Mount Pleasant Collegiate Institute (1853-1855) which became Iowa Wesleyan University in 1855. Harlan was elected United States Senator in 1855 and served until May, 1865 when he took up an appointment as Secretary of the Interior. He resigned in July, 1866 and was re-elected to the Senate until 1872 when he was defeated by William B. Allison. ${ }^{1}$ During these years of service in Washington, D. C., Harlan maintained his residence in Mount Pleasant in a house which is the core of the Harlan House Hotel. After 1873 he lived in a second house which is the Harlan-Lincoln Home on the campus of Iowa Wesleyan College.

Mary Eunice Harlan attended Iowa Wesleyan University preparatory department for most of the years between 1854 and 1863 and was enrolled in the university course 1862-1863. ${ }^{2}$ She married Robert Todd Lincoln, son of the late President Abraham Lincoln, in Washington, D. C., on Sept. 24, 1868, and moved to Chicago where her husband had established his law firm. ${ }^{3}$ Because of easy railroad transportation from Chicago, she often visited her parents in Mount Pleasant. These visits became more frequent when Senator Harlan retired after 1873 into his new home, north of the Iowa Wesleyan University campus.

In the late $1870 \mathrm{~s}$ and through the $1880 \mathrm{~s}$, Mrs. Robert T. Lincoln used her father's home in Mount Pleasant as a summer residence for herself and her three children. Robert T. Lincoln spent occasional Sundays with the family. ${ }^{4}$ Mrs.

1"James Harlan" in Dictionary of American Biography; Johnson, Brigham, James Harlan (State Historical Society of Iowa, 1913).

${ }^{2}$ Iowa Wesleyan University Catalogs 1854-1863.

"Robert Todd Lincoln" in Dictionary of American Biography; Ruth Painter Randall, Lincoln's Sons (Little, Brown and Company, 1955). 246, 256; John S. Goff, Robert Todd Lincoln (University of Oklahoma Press, forthcoming 1968), the first full scale biography.

${ }^{4}$ The Mount Pleasant Journal, Nov. 20, 1872; June 24, 1873; Jan. 27, 1876; July 13, 1876; Aug. 3, 1876; March 8, 1877; Sept. 20, 1877; Jan. 24, 1878; June 6, 1878; June 5, 1879; Oct. 16, 1879; Feb. 19, 1880; April 15, 1880; Jan. 6, 1881; May 25, 1882; June 8, 1882; Sept. 28, 1882; Oct. 5, 1882; Sept. 6, 1883; Sept. 13, 1883; Sept. 20, 1883. 
James Harlan died in 1884; thus Mrs. Robert T. Lincoln had additional reason for spending time with her father, and her three children, Mary (born Oct. 15, 1869), Abraham (Jack) II (born Aug. 14, 1873), and Jessie (born Nov. 6, $1875)^{6}$ lived many months each year in Mount Pleasant and entered into the life of the community. ${ }^{7}$ Mary and Jessie Lincoln were piano students in the summer session of Iowa Wesleyan in 1886, and Mary became a member of the Mount Pleasant Chapter A of the P.E.O. Sisterhood on Sept. 17, 1884; Jessie was initiated into the same organization on Dec. $31,1895 .^{9}$

In 1889, Robert Todd Lincoln was appointed Minister to the Court of St. James and he and his family moved to London. The son, Jack, was sent to France to school to perfect his French before entering Harvard. In France he contracted a carbuncle which became seriously infected; in spite of removal to England and the best medical care, the infection developed beyond control and the young man died on March 5, 1890. ${ }^{10}$ The family was stricken with grief and a desire to avoid London was soon evident.

That summer Mrs. Robert T. Lincoln returned to Mount Pleasant with Mary and Jessie and spent the next fall and winter there ${ }^{11}$ Robert $\mathrm{T}$. Lincoln arrived for a shorter stay in November, $1890 .^{12}$ During the academic year of 1890-1891, Jessie Harlan Lincoln was enrolled in the junior class of the preparatory department of Iowa Wesleyan University and as a voice student in the Iowa Wesleyan Conservatory of

${ }^{5}$ Ibid., Sept. 11, 1884; May 7, 1885; July 23, 1885; Aug. 6, 1885; Aug. 30, 1885; Sept. 3, 1885; Sept. 17, 1885; April 22, 1886; May 27, 1886; Aug. 12, 1886; Aug. 20, 1886; Aug. 26, 1886; April 14, 1887; May 9, 1887; Aug. 6, 1887; Aug. 18, 1887; Sept. 8, 1887; Oct. 20, 1887; July 19, 1888; Sept. 20, 1888; Oct. 25, 1888; April 11, 1889.

${ }^{6}$ Randall, op. cit., 264, 279, 290.

${ }^{7}$ The Mount Pleasant Journal. cf. dates under note 5.

${ }^{8}$ Iowa Wesleyan University Catalog 1886-1887.

${ }^{9}$ History of P.E.O. in Iowa (State P.E.O. Chapter, 1952), 194; Mary Lincoln was Roll No. 225; Jessie Lincoln was Roll No. 361. (Information furnished by National Headquarters of the P.E.O. Sisterhood).

${ }^{10}$ Randall, op. cit., 307-308. The Mount Pleasant Journal, Jan. 23, 1890; Feb. 6, 1890; Feb. 27, 1890; March 6, 1890.

${ }^{11}$ The Mount Pleasant Journal, Aug. 28, 1890.

${ }^{12}$ Ibid., Nov. 20, 1890. 
Music. ${ }^{13}$ In March, 1891, Mrs. Lincoln, with Mary and Jessie, returned to London. ${ }^{14}$ This $1890-1891$ enrollment of Jessie Lincoln is, no doubt, the event to which the unidentified clipping refers.

Robert T. Lincoln's term of appointment as American Minister extended to 1893, but Mrs. Lincoln and her daughters did not remain in England for that length of time. On Sept. 2, 1891, Mary Lincoln married Charles Isham, a secretary of the Ministry in London, and returned to New York City where he established a law practice. ${ }^{15}$ A son, Lincoln Isham, was born in New York on June 8, 1892. ${ }^{16}$ At this time or shortly afterwards, Mrs. Robert T. Lincoln and Jessie were in the United States, for by June 23, 1892, they were residing in Mount Pleasant. ${ }^{17}$ Jessie Lincoln again enrolled in the preparatory department of Iowa Wesleyan for part of the academic year $1892-1893 .{ }^{18}$ In October, 1892, Mrs. Charles Isham with her son and a nurse arrived in Mount Pleasant and remained there for a family visit until Nov. 17. ${ }^{19}$ Mrs. Robert T. Lincoln and Jessie stayed in Mount Pleasant until the end of November, 1892. They spent the rest of the winter, the spring and the summer in Chicago and New York City but came back to Mount Pleasant in October, 1893, for the next winter. ${ }^{20}$

When Robert T. Lincoln returned to the United States, Mrs. Lincoln and Jessie moved to the Chicago home, but made occasional visits to Mount Pleasant and to the east coast in the spring and summer of $1894 .^{21}$ Jessie Lincoln seems to have spent at least a part of the next winter with her grandfather in Mount Pleasant for she is listed as a voice student in the Iowa Wesleyan Conservatory of Music for 1894-1895. ${ }^{22}$ Her association with the University was some-

\footnotetext{
${ }^{13}$ Iowa Wesleyan University Catalog 1890-1891.

${ }^{14}$ The Mount Pleasant Journal, March 12, 1891.

${ }^{15}$ Randall, op. cit., 306.

${ }^{16}$ Ibid., 332. The Mount Pleasant Journal, June 23, 1892.

${ }^{17}$ Ibid.

${ }^{18}$ Iowa Wesleyan University Catalog 1892-1893.

${ }^{19}$ The Mount Pleasant Journal, Oct. 9, 1892; Nov. 17, 1892.

${ }^{20}$ Ibid., Dec. 29, 1892; Sept. 21, 1893; Oct. 26, 1893.

${ }^{21}$ Ibid., April 26, 1894; May 17, 1894; May 24, 1894; July 5, 1894.

${ }^{22}$ Iowa Wesleyan University Catalog 1894-1895.
} 
what sporadic but it did extend over several years. She never enrolled for any collegiate work nor did she receive any diploma.

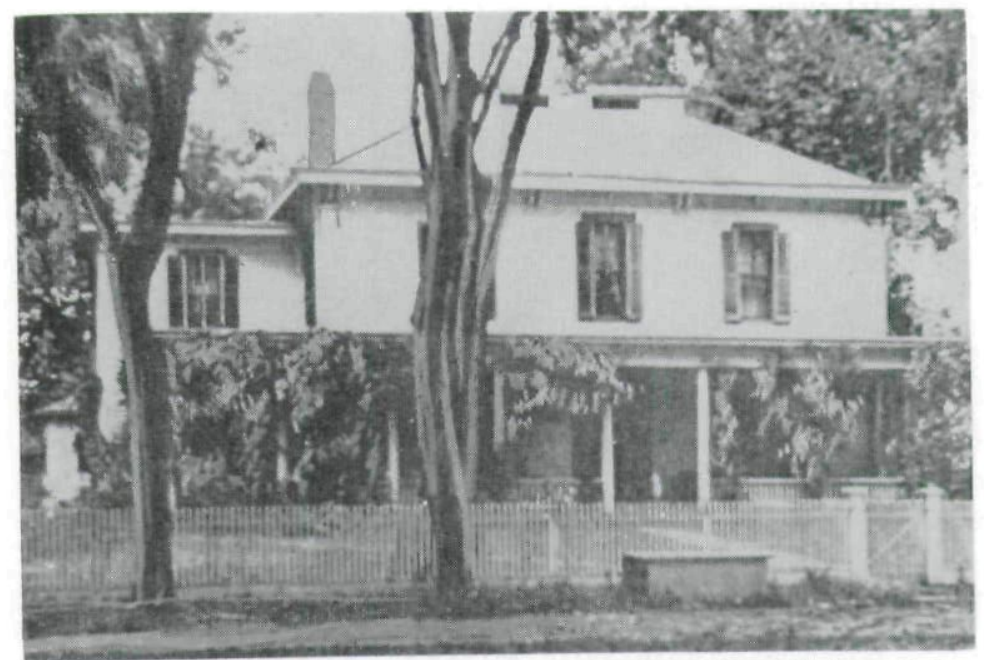

courtesy of Iowa Wesleyan College

\section{Sen. James Harlan's Mount Pleasant Home Photo shows original porch}

The residence of Mrs. Robert T. Lincoln and Jessie in Mount Pleasant became increasingly more prolonged in the next few years. They arrived in March, $1895 .^{23}$ Although Jessie was away on a summer trip with her father, Mrs. Lincoln remained in Mount Pleasant. ${ }^{24}$ In September, she made extensive additions to the porch on her father's house, participated in some social events and at least one wedding reception in the community and prepared for a visit by Mary Lincoln Isham and son. ${ }^{25}$ It was during this visit by Mrs. Isham that Mrs. Robert T. Lincoln gave two very elaborate evening receptions with printed invitations, hired caterer and orchestra for dancing. ${ }^{26}$ The provision for dancing caused some upheaval among the Methodist authorities at Iowa Wesleyan University since some students had been in-

${ }^{23}$ The Mount Pleasant Journal, March 7, 1895.

${ }^{24}$ Ibid., July 4, 1895; July 25, 1895; Aug. 8, 1895.

${ }^{25}$ Ibid., Sept. 5, 1895; Sept. 12, 1895; Oct. 3, 1895.

${ }^{26}$ Ibid., Oct. 10, 1895. 
cluded on the guest list. One student, Marsa Fee of Centerville, recalled that President Charles L. Stafford ordered her to leave the reception before the dancing commenced. ${ }^{27}$ The first reception was on Oct. 15, in honor of Mary Lincoln Isham's birthday. The second was on Nov. 5, in honor of Jessie Lincoln's birthday. The Mount Pleasant Journal printed glowing accounts of the elegance of these occasions. ${ }^{28}$ Some persons who had been guests saved their invitations for over 50 years and three of these are in the collection of the Harlan-Lincoln Home at Iowa Wesleyan College.

Again during 1896 and 1897, Mrs. Robert T. Lincoln and Jessie were in Mount Pleasant on frequent occasions. ${ }^{29}$ On Nov. 4, 1897 they left for Chicago for the winter and, on Nov. 10, 1897, Jessie Lincoln eloped from her parents' Chicago home with Warren W. Beckwith of Mount Pleasant and was married in Milwaukee. ${ }^{30}$

Warren W. Beckwith was the youngest son of Capt. Warren Beckwith of Mount Pleasant. After military service in the Civil War, Capt. Beckwith came to Mount Pleasant in the employment of the Burlington and Missouri River Railroad. In 1872 this line was consolidated with the Chicago, Burlington and Quincy Railroad and Capt. Beckwith obtained an administrative post. He left this position in 1879 when he, together with some other Mount Pleasant citizens, formed the Western Wheel Scraper Company in which he was a major stockholder and half owner of the patent. The company moved its factory to Aurora, Ill. in 1892, but Capt. Beckwith, although secretary and a member of the board of directors, maintained his Mount Pleasant residence and an extensive farm with a famed herd of 150 purebred Herefords and a collection of trotting horses. He was active in other business ventures in Mount Pleasant and Chicago, as well as in community and church life. ${ }^{31}$

${ }^{27}$ Mss. Recollections in Archives of Iowa Wesleyan College.

${ }^{28}$ The Mount Pleasant Journal, Oct. 17, 1895; Nov. 7, 1895.

${ }^{29}$ Ibid., Jan. 13, 1896; July 2, 1896; Dec. 3, 1896; April 8, 1897; May 6, 1897.

${ }^{30}$ Ibid., Nov. 4, 1897; Nov. 18, 1897.

${ }^{31}$ Biographical Review of Henry County, Iowa (Hobart Publishing Company, Chicago, 1906), 11-14. 
Warren W. Beckwith attended Kemper Hall, an Episcopal school in Davenport, Iowa, and was well-known for his athletic ability in football and baseball. In 1891-1893 he was enrolled in the preparatory department of Iowa Wesleyan University at the same time that Jessie Lincoln was a student. $^{32}$ During the year 1893-1894 he was not enrolled, but in 1891-1895 he was a student in the Commercial Department of the University. ${ }^{32}$ Collegiate athletics were somewhat unorganized at this time and more or less depended upon volunteer groups. In September, 1891, an Iowa Wesleyan football team was formed with Warren Beckwith as quarterback. This team played Parsons College, Fairfield, losing 14-6. ${ }^{33}$ The Archives of Iowa Wesleyan College contains a photograph of this team with Warren Beckwith on the right end of the second row. During the next year he held several business positions and in June 1896 went to Chicago to work for the Gas and Coke Company of Chicago. ${ }^{34}$

It is evident that Jessie Lincoln and Warren Beckwith were students at the same time on several occasions at Iowa Wesleyan, that they had grown up in Mount Pleasant during the many extended visits of Jessie Lincoln and that the social-economic status of the two families made friendship possible. It was stated in the Mount Pleasant Journal at the time of the elopement that the families were friends of long standing.

Following the marriage, Jessie Lincoln Beckwith lived in Mount Pleasant while her husband engaged in cattle ranching in Indian Territory (Oklahoma) and in the area of Creston, Iowa, as well as during the time of his enlistment in the United States Army for the Spanish-American War. ${ }^{35}$ The first child, Mary Lincoln Beckwith, was born in Mount Pleasant on Aug. 22, $1898 .^{36}$ The Beckwith's later moved to

${ }^{32}$ Iowa Wesleyan University Catalog 1891-1892; 1892-1893; 1894-1895.

${ }^{33}$ The Iowa Wesleyan, (Sept. 29, 1894), 14.

${ }^{34}$ The Mount Pleasant Journal, Jan. 16, 1896.

${ }^{35}$ Ibid., Jan. 6, 1898; Jan. 26, 1898; Feb. 23, 1898; March 3, 1898; March 17, 1898; April 28, 1898; May 19, 1898; July 7, 1898; Aug. 4, 1898; Oct. 6, 1898; Dec. 5, 1898.

${ }^{36} \mathrm{R}$. Gerald McMurtry, The Harlan-Lincoln Tradition at Iowa Wesleyan College (Mt. Pleasant, 1959), 15 n. 3 
the Chicago area where their son, Robert Todd Lincoln Beckwith, was born on July 19, 1904, in Riverside, Ill. ${ }^{37}$ This marriage was terminated by a divorce in 1907, and Jessie Lincoln Beckwith's ties to Mount Pleasant through the Beckwith family ceased. ${ }^{38}$ She subsequently married Frank Edward Johnson and Robert J. Randolph. ${ }^{39}$

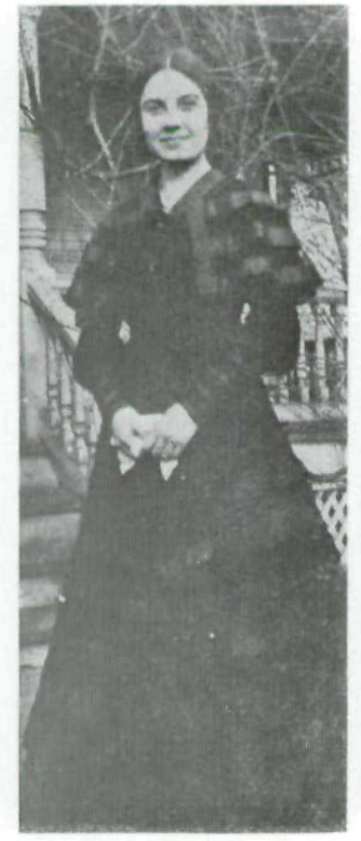

courtesy of Iowa Wesleyan College

\section{Jessie Harlan Lincoln}

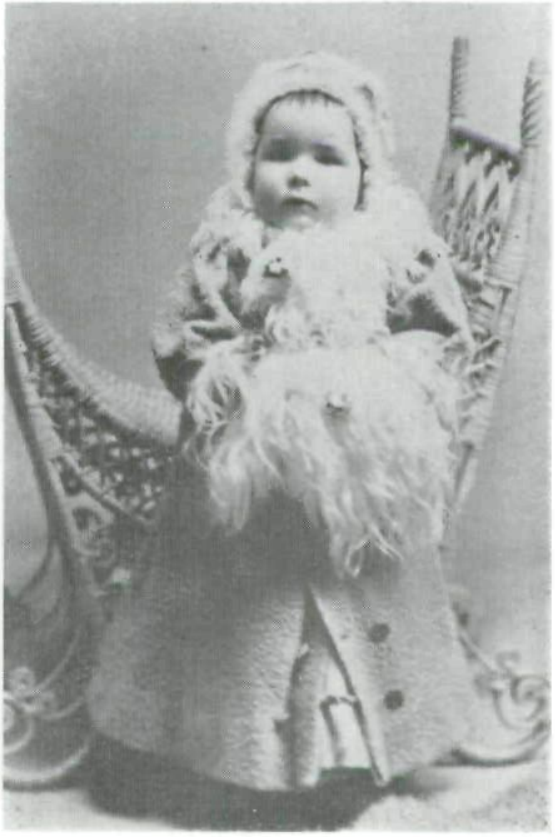

courtesy of Iowa Wesleyan College

Mary Lincoln Beckwith

Mrs. Robert T. Lincoln's connections with Mount Pleasant also were lessened after Oct. 5, 1899 when her father, James Harlan, died. ${ }^{40}$ She spent time in Mount Pleasant settling his estate which was completed in April, 1902, with the pro-

${ }^{37} \mathrm{Ibid}$.

${ }^{38} \mathrm{Ibid}$., Cf. interview with Warren W. Beckwith, Chicago Tribune, March 20, 1950.

${ }^{39}$ McMurtry, op. cit., 15 n. 3; Randall, op. cit., 334.

${ }^{40}$ The Mount Pleasant Journal, Oct. 6, 1899; Oct. 10, 1899; Oct. 13, 1899; Nov. 21, 1899. 


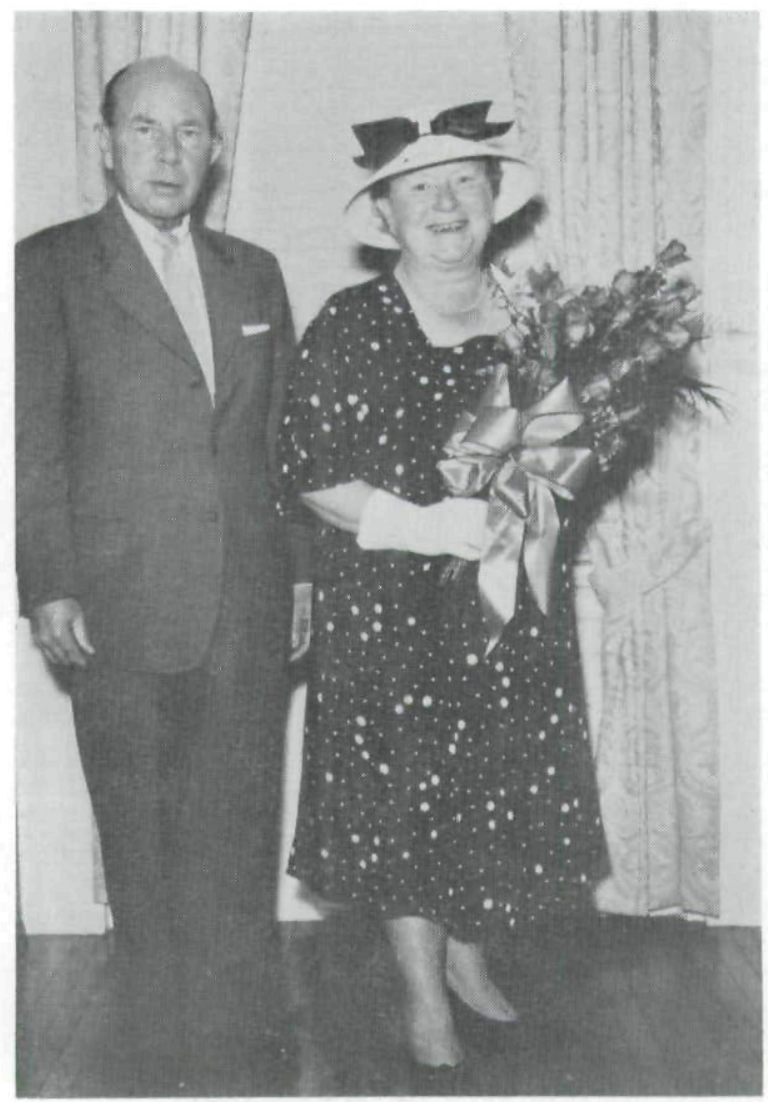

official photo of the U.S. Navy

Robert Todd Lincoln and Mary Lincoln Beckwith, May, 1960 bate of the will. In May, 1907, she presented Harlan's house and some furnishings to Iowa Wesleyan University. ${ }^{41}$ The Robert Todd Lincolns sold their Chicago home in 1911 and moved to Washington, D. C., and began to spend the summers at "Hildene," near Manchester, Vt. ${ }^{42}$ Mrs. Lincoln apparently never returned to Mount Pleasant after 1911. Robert Todd Lincoln died in 1926, but Mrs. Lincoln lived until

${ }^{41}$ The Mount Pleasant Daily News, May 24, 1907. Louis A. Haselmayer, The 125th Anniversary History of Iowa Wesleyan College (Mt. Pleasant, 1967), 27.

${ }^{42}$ Randall, op. cit., 337-339. 
March 31, 1937, dying at the age of $90 .^{43}$ It was somewhat of a surprise in April, 1937, when it was revealed that the estate of Mrs. Lincoln was to remain intact with life interest for her children and grandchildren and that, if at any time the blood line should die out, the estate should be divided equally by The American Red Cross, The First Church of Christ, Scientist and Iowa Wesleyan College, the latter bequest as a memorial to her father. ${ }^{44}$

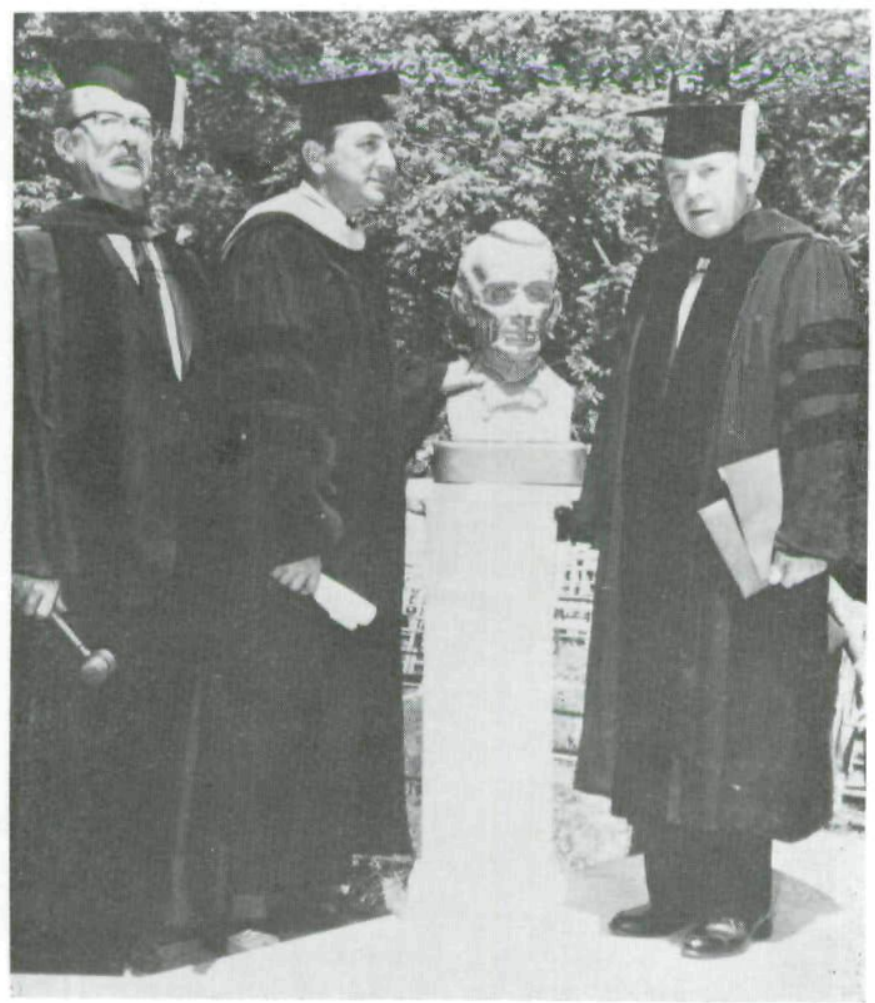

courtesy of Iowa Wesleyan College

Carl Haverlin, Pres. John W. Henderson and Robert Todd Lincoln Beckwith at lowa Wesleyan College, May, 1965, after Beckwith received an honorary LL.D.

${ }^{43}$ Ibid., 340; The Mount Pleasant Daily News, March 31, 1937; New York Times, April 1, 1937.

${ }^{44}$ The Mount Pleasant Daily News, April 13, 1937; J. Raymond Chadwick, "Lincoln and the Harlan Family," Annals of Iowa (April, 1959), 3rd Series, XXXIV, No. 8, 619, 623. 
Jessie Lincoln likewise never returned to Mount Pleasant and died in 1948. ${ }^{45}$ The children of Jessie Lincoln Beckwith grew up in Chicago, Washington, D. C., and Manchester, Vt., having no connections with Mount Pleasant until 1965. In that year, her son, Robert Todd Lincoln Beckwith, visited Iowa Wesleyan College at the June Commencement to receive an honorary LL.D. degree. ${ }^{46}$

${ }^{45}$ McMurtry, op. cit., 11.

${ }^{46}$ Haselmayer, op. cit., 56.

\title{
AN IOWA DOUGHBOY'S VIEW OF WORLD WAR I
}

\author{
By Joseph H. Peiffer \\ Edited by Virgil J. Vogel \\ Chicago City College
}

The year 1968 marks the 50th anniversary of the participation of American soldiers in large scale campaigns of the first World War, since only token contingents arrived in France during the first year of the war. This event has attracted nothing like the attention which was devoted, a short while ago, to the centennial of the Civil War. We need not here seek the reasons for this phenomenon, but we can note the hard fact that the ranks of those two millions who crossed the sea "to repay the debt of Lafayette" are rapidly thinning. Most of them will undoubtedly carry with them, beyond all recall, priceless recollections of the events of 1918 which could illuminate for future generations what it was like to be a participant in the first large-scale modern war, in which technology played an important role, and which has left deep marks on the shape of today's world.

The books which describe the political, diplomatic, and military maneuvers of that war fill many shelves, and others continue to appear. What most of them lack, however, is a 
Copyright of Annals of Iowa is the property of State of Iowa, by \& through the State Historical Society of Iowa and its content may not be copied or emailed to multiple sites or posted to a listserv without the copyright holder's express written permission. However, users may print, download, or email articles for individual use. 